\title{
Partial purification of the protein moiety of porcine tissue thromboplastin
}

\author{
Citation for published version (APA):
}

Wijngaards, G., Hemker, H. C., \& van Deenen, L. L. M. (1977). Partial purification of the protein moiety of porcine tissue thromboplastin. Haemostasis, 6(5), 269-282. https://doi.org/10.1159/000214192

Document status and date:

Published: 01/01/1977

DOI:

10.1159/000214192

Document Version:

Publisher's PDF, also known as Version of record

\section{Please check the document version of this publication:}

- A submitted manuscript is the version of the article upon submission and before peer-review. There can be important differences between the submitted version and the official published version of record.

People interested in the research are advised to contact the author for the final version of the publication, or visit the DOI to the publisher's website.

- The final author version and the galley proof are versions of the publication after peer review.

- The final published version features the final layout of the paper including the volume, issue and page numbers.

Link to publication

\footnotetext{
General rights rights.

- You may freely distribute the URL identifying the publication in the public portal. please follow below link for the End User Agreement:

www.umlib.nl/taverne-license

Take down policy

If you believe that this document breaches copyright please contact us at:

repository@maastrichtuniversity.nl

providing details and we will investigate your claim.
}

Copyright and moral rights for the publications made accessible in the public portal are retained by the authors and/or other copyright owners and it is a condition of accessing publications that users recognise and abide by the legal requirements associated with these

- Users may download and print one copy of any publication from the public portal for the purpose of private study or research.

- You may not further distribute the material or use it for any profit-making activity or commercial gain

If the publication is distributed under the terms of Article $25 \mathrm{fa}$ of the Dutch Copyright Act, indicated by the "Taverne" license above, 


\title{
Partial Purification of the Protein Moiety of Porcine Tissue Thromboplastin
}

\author{
G. WijngaArds, H. C. Hemker and L. L. M. van Deenen \\ Laboratory of Biochemistry, University of Utrecht, \\ University Centre 'De Uithof', Utrecht; \\ Department of Biochemistry, State University Limburg, Maastricht; \\ and Gaubius Institute, Health Research Organization TNO, Leiden
}

Key Words. Tissue thromboplastin · Porcine lung · Purification

Abstract. The tissue thromboplastin activity of porcine lung was separated from an aqueous tissue extract by differential centrifugation. Repeated suspension and sedimentation yielded a thromboplastin preparation free of soluble protein.

The most effective delipidation of the lyophilized preparation with minimum denaturation of the protein moiety of thromboplastin was achieved using $n$-heptane/ $n$-butanol extraction. A detergent was required to solubilize the thromboplastin protein moiety from the delipidated preparation. Gel filtration in the presence of detergent permitted further delipidation of the protein moiety and yielded a purified protein moiety. Apparent homogeneity was observed for the purified protein with several fractionation techniques. This apparently homogeneous protein dissociates into the constituent proteins in the presence of dodecyl sulphate. The aggregation of proteins is ascribed to their hydrophobic nature. Gel filtration on Bio-Gel A-1.5 m was found to be useful in the separation of the dodecyl sulphate-protein complexes on a preparative scale. Following the removal of the dodecyl sulphate, the renaturation of the thromboplastin protein moiety was unsuccessful.

The purified protein moiety with its low lipid content $(1 \%)$ is suitable for lipid requirement studies.

\section{Introduction}

The high clot-promoting activity of various tissue extracts is attributed to the presence of tissue thromboplastin, which is the activator of the extrinsic blood coagulation mechanism $[18,33]$. It is bound to subcellular

Received: April 25, 1977; in revised form: July 25, 1977; accepted by editor K. LECHNER: July 25, 1977. 
particles [5-7, 31, 32]. Thromboplastin preparations contain both lipid and protein material. Extraction of lyophilized preparations by organic solvents results in a loss of the high procoagulant activity, but the activity can be restored under certain conditions by recombination of the two moieties [8, $13,17,19,25]$.

With the purified protein moiety of tissue thromboplastin, it is possible to study the lipid requirements of the protein, the activating principle of factor VII, the occurrence and localization of thromboplastin in tissues, its possible release into the blood under different conditions and its fate thereafter. There have been several reports on the purification of the protein moiety of thromboplastin derived from bovine tissue $[15,20,21]$, canine tissue [9] and human tissue $[10,18]$. However, the procedures result in preparations which are either still contaminated with other proteins, have low solubility in aqueous media in the absence of detergent, contain too little protein for extensive studies or contain a thromboplastin which cannot activate human factor VII.

We have recently demonstrated that tissue thromboplastin from porcine lung activates human factor VII, whereas that from bovine tissue does not [30]. Therefore, porcine lung thromboplastin seems to be a suitable preparation for investigating the function of thromboplastin in the activation of human factor VII and the lipid requirements of tissue thromboplastin. An important advantage with respect to the purification and subsequent studies is the ready availability of a large supply of porcine lung tissue.

In the present study, the protein fraction of porcine lung thromboplastin was subjected to fractionation techniques which resulted in a partially purified protein moiety. The phospholipid requirements of this protein are described in a subsequent paper [29].

\section{Materials and Methods}

Porcine lung thromboplastin was prepared according to the method of CHARGAFF et al. [5], with some modifications [30]. Fresh lungs were washed, cut into pieces and homogenized after the addition of saline. Large particles and connective tissue were removed by centrifugation $(1,250 \mathrm{~g}$ for $10 \mathrm{~min}$ ) after which the supernatant was subjected to two successive centrifugations at $2,500 \mathrm{~g}$ for $45 \mathrm{~min}$. Thromboplastin was sedimented from the final supernatant at $100,000 \mathrm{~g}$ for $60 \mathrm{~min}$ and suspended in borate buffer (I $0.15, \mathrm{pH}$ 8.6). This suspension was subjected to ultracentrifugation $(100,000 \mathrm{~g}$ for $60 \mathrm{~min})$ and resuspension in borate buffer 4 times. It was subsequently washed 4 times using distilled water. This resulted in a purified thromboplastin preparation which was free of soluble proteins. Finally, the grey-coloured pellet was lyophilized and stored at $-20^{\circ} \mathrm{C}$. 
Human brain thromboplastin was prepared from acetone-dried tissue as described by Hecht and OOSTERBAaN-VAN Lit [12].

Extraction of porcine lung thromboplastin. Lyophilized thromboplastin $(1 \mathrm{~g})$ was extracted with $n$-heptane/ $n$-butanol $2 / 1(\mathrm{v} / \mathrm{v})(100 \mathrm{ml})$ by stirring for $30 \mathrm{~min}$ at room temperature; this was followed by sedimentation for $15 \mathrm{~min}$ at $1,000 \mathrm{~g}$. The supernatant was used for the isolation of the phospholipids and the pellet was extracted 4 more times with the same solvent system. The pellet was finally dried under vacuum for $16 \mathrm{~h}$ and stored at $-20^{\circ} \mathrm{C}$.

Gel filtration. $n$-Heptane/ $n$-butanol extracted porcine lung thromboplastin (200 mg) was solubilized in Veronal-chloride buffer ( $10.015, \mathrm{pH} 7.35 ; 15 \mathrm{ml}$ ) containing $1 \%$ sodium deoxycholate by homogenization in a Potter-Elvehjem tube and by stirring for $1 \mathrm{~h}$ at room temperature. Insoluble material was removed by sedimentation at $20,000 \mathrm{~g}$ for $15 \mathrm{~min}$. After the addition of sucrose $(500 \mathrm{mg})$ to the supernatant, the sample was placed onto a Sephadex G-200 column $(60 \times 3 \mathrm{~cm})$ or a Sepharose- $6 \mathrm{~B}$ column beneath an eluant layer of $3-5 \mathrm{~cm}$. The column, which has been equilibrated with $0.25 \%$ sodium deoxycholate in Veronal-chloride buffer (I 0.015, pH 7.35), was eluated with the same buffer at a flow rate of $12 \mathrm{ml} / \mathrm{h}$. Fractions of $9 \mathrm{ml}$ were collected and tested for protein and phosphorus content. A $1.0-\mathrm{ml}$ volume of the fraction was dialyzed against Veronal-chloride buffer (I $0.015, \mathrm{pH} 7.35$ ) for $48 \mathrm{~h}$ followed by the addition of $1.5 \mathrm{mg}$ phospholipid mixture of thromboplastin, solubilized in $0.5 \mathrm{ml}$ acetate buffer (I $0.01, \mathrm{pH} 4.0$ ) containing $1.5 \%$ sodium taurocholate. The detergent was subsequently removed by dialysis against acetate buffer for $65-70 \mathrm{~h}$ as described by WIJNGAARDS et al. [29]. The recombinants were tested for thromboplastin activity.

The remaining volumes $(8 \mathrm{ml})$ of the fractions which showed thromboplastin activity were combined, dialyzed against Veronal-chloride buffer for about $90 \mathrm{~h}$ and concentrated by dialysis against $10 \%$ polyethylene glycol (molecular weight 20,000 ) in the same buffer. The concentrated preparation (1-1.5 mg protein per millilitre) was subjected to further purification techniques.

Gel filtration in the presence of KSCN, ethanol or guanidine hydrochloride was performed by adding these reagents to all solutions which were involved in the separation. Rheomacrodex (molecular weight 40,000 ) was added as a $10 \%$ solution in saline.

Sodium dodecyl sulphate polyacrylamide gel electrophoresis was performed according to the method of SHAPIRo et al. [24] using a Shandon Disc electrophoresis apparatus. The electrophoresis time was $3.5 \mathrm{~h}$ with a constant current of $5 \mathrm{~mA}$ per tube. The gels were fixed in $10 \%$ trichloroacetic acid for $16 \mathrm{~h}$ and stained for $1 \mathrm{~h}$ in $0.25 \%$ Coomassie brilliant blue R-250 dissolved in methanol/acetic acid/water 5/1/5 (v/v/v). The gels were decolourized in the same solvent system and stored in $7 \%$ acetic acid.

The dodecyl sulphate-protein complexes were fractionated on a preparative scale with the same gel composition using the Buchler 'Poly Prep' apparatus.

Gel filtration of dodecyl sulphate-protein complexes was performed in Veronal-chloride buffer (I $0.015, \mathrm{pH} 7.35$ ) containing $0.025 \%$ sodium dodecyl sulphate on Bio-Gel A-1.5 m at room temperature. The protein sample was incubated in the Veronal-chloride buffer containing $1.0 \%$ sodium dodecyl sulphate for $3 \mathrm{~h}$ at $37^{\circ} \mathrm{C}$ before application to the column.

Isolation of phospholipids from porcine lung thromboplastin extract. The $n$-heptane/ $n$-butanol extract of $3 \mathrm{~g}$ of thromboplastin was evaporated and dried under reduced pres- 
sure and dissolved in $50 \mathrm{ml}$ of chloroform. This solution was applied to a silicic acid column (Mallinckrodt, analytical grade, $60-140$ mesh; $17 \times 4.5 \mathrm{~cm}$ ) previously equilibrated with chloroform. Neutral lipids were eluted with chloroform/methanol mixtures containing 5 and $10 \%(v / v)$ methanol. This was followed by the elution of the phospholipids. For that purpose, the methanol concentration was stepwise increased from 15 to $60 \%(\mathrm{v} / \mathrm{v})$. These fractions were combined and evaporated and the residue was dissolved in $n$-pentane. Traces of silicic acid were removed by the addition of $5 \%(\mathrm{v} / \mathrm{v})$ of water followed by centrifugation for $20 \mathrm{~min}$ at $2,000 \mathrm{~g}$ at room temperature. The supernatant was evaporated and the phospholipid mixture was dissolved in $n$-pentane, which had been dried with anhydrous sodium carbonate, and stored under nitrogen at $-20^{\circ} \mathrm{C}$.

Thin-layer chromatography of phospholipids. Samples were acidified to $\mathrm{pH} 2$ with $\mathrm{HCl}$ and the lipids extracted as described by BLIGH and DYER [3]. The lipid extracts were chromatographed two-dimensionally on silica gel HR to which $2 \%$ magnesium silicate $(w / w)$ had been added following the method of BROEKHUYSE [4].

The spots were visualized by spraying with $20 \% \mathrm{H}_{2} \mathrm{SO}_{4}$ and heating for $2-3 \mathrm{~h}$ at $180^{\circ} \mathrm{C}$. The amount of phosphorus in the spots was determined by the method of RousER et al. [22].

Thromboplastin activity was estimated by the two-stage assay described elsewhere [30]. The first stage involved an incubation of purified human factor VII with the sample in the presence of calcium chloride. The degree of activation of factor VII was subsequently determined in a clotting system consisting of artificially depleted factor VII reagent, a phospholipid suspension and calcium chloride. The degree of activation was found to be directly proportional to the thromboplastin activity of the sample.

The activity was calculated from the clotting time with the aid of a standard curve and it was expressed in percent activity with reference to an equal amount of standard recombinant [29].

Protein was measured by the method of LowRy et al. [16].

Phosphorus content was determined according to the method of BARTLETT [1].

\section{Results}

\section{Delipidation of Tissue Thromboplastin}

Different organic solvent systems were tested for their capacity to extract the lipids of lyophilized thromboplastin. These included $n$-butanol, petroleum ether, ether, ether/ethanol mixtures, pyridine, pyridine/chloroform mixtures and acetone/water at $-15^{\circ} \mathrm{C}[23]$.

These procedures resulted in protein fractions which still contained too much lipid material or which did not demonstrate clot-promoting activity after recombination with the lipid fraction [28]. In addition, the solubility of the protein fractions in aqueous media without a detergent was very low. Techniques employing an aqueous and an organic liquid phase always produced protein fractions devoid of the clot-promoting property. 
Table I. Protein and phosphorus content $( \pm \mathrm{SD} ; \mathrm{n}=4)$ of porcine lung thromboplastin (PLTP) and its fractions

\begin{tabular}{llll}
\hline Preparation & $\begin{array}{l}\text { Protein } \\
\%\end{array}$ & $\begin{array}{l}\text { Lipid } \\
\text { phosphorus } \\
\mu \mathrm{g} / \mathrm{mg}\end{array}$ & $\begin{array}{l}\text { Non-lipid } \\
\text { phosphorus } \\
\mu \mathrm{g} / \mathrm{mg}\end{array}$ \\
\hline PLTP & $39.9 \pm 5.6$ & $15.7 \pm 0.3$ & $2.93 \pm 0.81$ \\
$n$-Heptane/ $n$-butanol-extracted PLTP & $76.9 \pm 3.8$ & $1.73 \pm 0.03$ & $3.95 \pm 0.06$ \\
$\begin{array}{l}\text { Purified protein moiety of PLTP } \\
\text { from gel filtration on Sephadex G-200 }\end{array}$ & $74.0 \pm 2.2$ & $0.42 \pm 0.08$ & $1.69 \pm 0.21$ \\
\hline
\end{tabular}

${ }^{1}$ The phospholipid content is about 25 times that of the lipid phosphorus content.

Table II. Phospholipid composition of porcine lung thromboplastin (PLTP) and its fractions

\begin{tabular}{lcllll}
\hline Phospholipid & $\begin{array}{l}\text { PLTP } \\
\%\end{array}$ & $\begin{array}{l}\text { n-Heptane/n-butanol } \\
\text { extract of PLTP } \\
\%\end{array}$ & $\begin{array}{l}\text { Delipidated } \\
\text { PLTP } \\
\%\end{array}$ & $\begin{array}{l}\text { Phospholipid peak } \\
\text { from Sephadex G-200 } \\
\%\end{array}$ & $\begin{array}{l}\text { Purified protein } \\
\text { moiety of PLTP } \\
\%\end{array}$ \\
\hline PE & 15.6 & 15.4 & 13.7 & 16.5 & - \\
Lyso PE & - & - & 2.6 & 4.1 & - \\
PC & 66.4 & 64.9 & 6.2 & 3.2 & - \\
Lyso PC & 5.3 & 6.5 & 1.8 & 0.8 & - \\
PS & 7.4 & 6.8 & 38.5 & 33.6 & - \\
Lyso PS & - & - & 5.2 & 9.0 & - \\
PA & - & - & 2.5 & 2.9 & - \\
PI & trace & trace & 18.7 & 19.4 & 7.4 \\
Sphingomyelin & 5.3 & 5.4 & 0.7 & 0.2 & - \\
NI (CL?) & trace & 0.9 & 5.2 & 5.1 & \\
NI (3 spots) & - & - & 4.9 & 5.2 & \\
\hline
\end{tabular}

$\mathrm{PE}=$ Phosphatidylethanolamine $\mathrm{PC}=$ phosphatidylcholine; $\mathrm{PS}=$ phosphatidylserine;

$\mathrm{PA}=$ phosphatidic acid; $\mathrm{PI}=$ phosphatidylinositol $\mathrm{CL}=$ cardiolipin; $\mathrm{NI}=$ not identified. 
The extraction of lyophilized porcine lung thromboplastin with $n$-heptane/n-butanol $2 / 1(\mathrm{v} / \mathrm{v})$ as used by Nemerson [19] to delipidate acetonedried bovine lung and brain tissue was more suitable. Besides the neutral lipids, about $90 \%$ of the phospholipids could be extracted (table I). Thinlayer chromatography and phosphorus analysis revealed that the remaining phospholipid content consisted predominantly of phosphatidylserine, phosphatidylinositol and phosphatidylethanolamine (table II). The solubility of the heptane/butanol-extracted thromboplastin was low in Veronalchloride buffer (I $0.015, \mathrm{pH} 7.35$ ) but could be markedly increased by the addition of sodium deoxycholate $(1 \%)$.

\section{Purification by Gel Filtration}

Gel filtration of solubilized heptane/butanol-extracted porcine lung thromboplastin on Sephadex G-200 in the presence of $0.25 \%$ sodium deoxycholate resulted in an elution pattern as shown in figure 1 . The protein material was regained almost entirely in one peak, while most of the phosphorus-containing components were eluted in two peaks which were separate from the protein peak. These two phosphorus peaks were found to contain lipid-phosphorus (fractions 26-40) and non-lipid-phosphorus (fractions 41-53). Recombination of each fraction with the phospholipid mixture of thromboplastin showed that the protein moiety of thromboplastin was localized mainly in the second part of the protein peak corresponding with a molecular weight of about 300,000 . The recovery of the activity was rather low $(10-15 \%)$. However, it was demonstrated that this was not due to inactivation but to the phospholipid mixture of thromboplastin which did not fulfil the lipid requirements of the protein for maximum activity. A 3- to 4 -fold increase in the recombinant activity could be obtained by enrichment of this mixture with phosphatidylserine [29]. The lipid-phosphorus content of the pooled active fractions amounted to $0.42 \mu \mathrm{g}$ phosphorus per milligram protein. This corresponds to about $1 \%$ phospholipid (table I) consisting predominantly of phosphatidylserine and phosphatidylinositol (table II). Removal of deoxycholate by dialysis against buffers with a $\mathrm{pH}$ above 7 always resulted in clear solutions. Lyophilization of this solution yielded a protein preparation which exhibited a rather low solubility in detergent-free media. However, concentration by dialysis against $10 \%$ polyethylene glycol (molecular weight 20,000 ) was a suitable following step.

To achieve a better resolution in the protein peak, Sepharose 6B was tested. Here, the protein material appeared as two peaks with the highest 


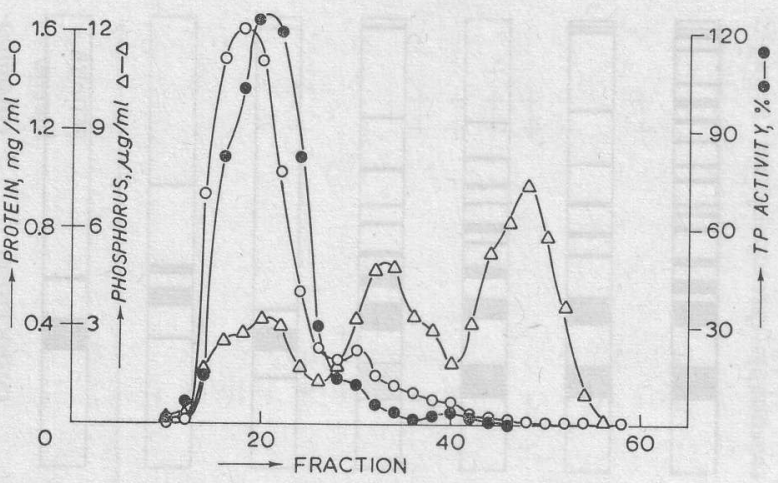

Fig. 1. Gel filtration of delipidated porcine lung thromboplastin on Sephadex G-200 in the presence of $0.25 \%$ sodium deoxycholate.

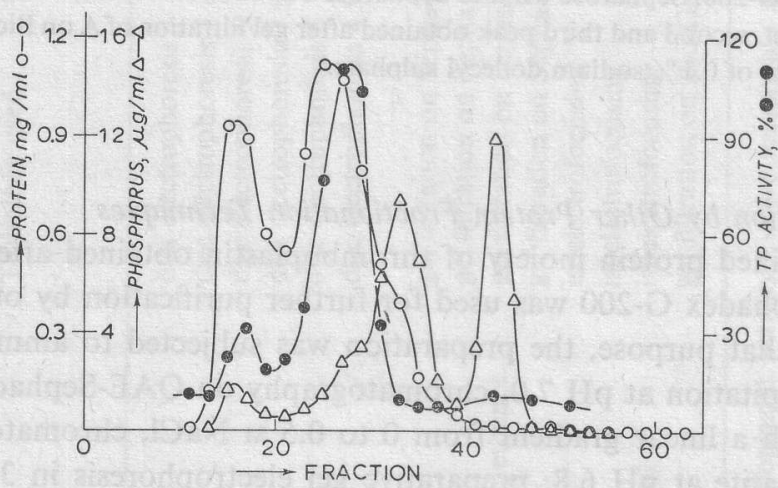

Fig. 2. Gel filtration of delipidated porcine lung thromboplastin on Sepharose 6B in the presence of $0.25 \%$ sodium deoxycholate.

specific activity of the protein moiety of thromboplastin being localized in the second half of the second protein peak (fractions 24-33; fig. 2). On analytical electrophoresis, the number of protein bands in the combined active fractions was not smaller than was found with Sephadex G-200 (fig. 3). Furthermore, there was some overlap by the phospholipid peak (fractions 25-39) which adversely affected the lipid content of the partially purified protein moiety of thromboplastin. The presence of Rheomacrodex $(2 \%)$ during the separation had not the influence on the elution characteristics it was reported to have [14]. 


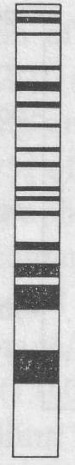

A

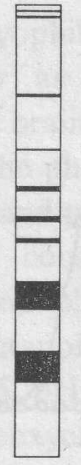

B

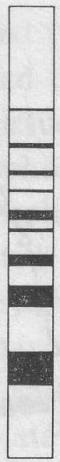

C

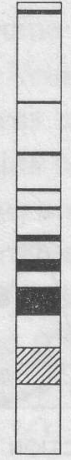

D

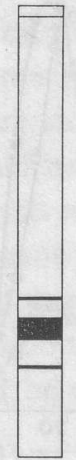

E

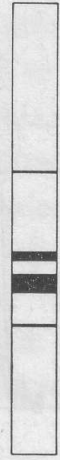

$\mathrm{F}$

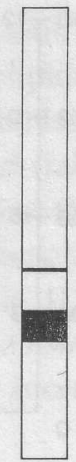

G

Fig. 3. Polyacrylamide gel electrophoresis in the presence of $0.1 \%$ sodium dodecyl sulphate. $\mathrm{A}=n$-Heptane/ $n$-butanol-extracted porcine lung thromboplastin; $\mathrm{B}, \mathrm{C}, \mathrm{D}=$ partially purified protein moiety of porcine lung thromboplastin obtained after gel filtration on Sephadex G-200, Sepharose 6B and Sepharose 6B+2\% Rheomacrodex, respectively; $\mathrm{E}, \mathrm{F}, \mathrm{G}=$ first, second and third peak obtained after gel filtration of A on Bio-Gel A-1.5 m in the presence of $0.1 \%$ sodium dodecyl sulphate.

\section{Purification by Other Protein Fractionation Techniques}

The purified protein moiety of thromboplastin obtained after gel filtration on Sephadex G-200 was used for further purification by other techniques. For that purpose, the preparation was subjected to ammonium sulphate precipitation at $\mathrm{pH} 7.0$, chromatography on QAE-Sephadex A-50 at $\mathrm{pH} 7.4$ with a linear gradient from 0 to $0.5 \mathrm{M} \mathrm{NaCl}$, chromatography on hydroxylapatite at $\mathrm{pH} 6.8$, preparative gel electrophoresis in $3.75 \%$ polyacrylamide at $\mathrm{pH} 7.35$ and isoelectric fractionation. However, none of these techniques was effective in further purifying the partially purified protein moiety. Isoelectric focusing showed the thromboplastin protein moiety to be present in the main protein peak at $\mathrm{pH} 4.8-5.2$.

\section{Formation and Dissociation of Protein Aggregates}

The pattern obtained by analytical polyacrylamide gel electrophoresis of the partially purified protein moiety of thromboplastin showed some protein material migrating diffusely into the gel and much protein at the top of the gel. This observation and those of the other fractionation techniques suggest that the purified protein moiety consisted of aggregates. This prompted us to study the effect of various dissociating agents on the aggregates using different techniques. Optimal dissociation was achieved in the presence of 


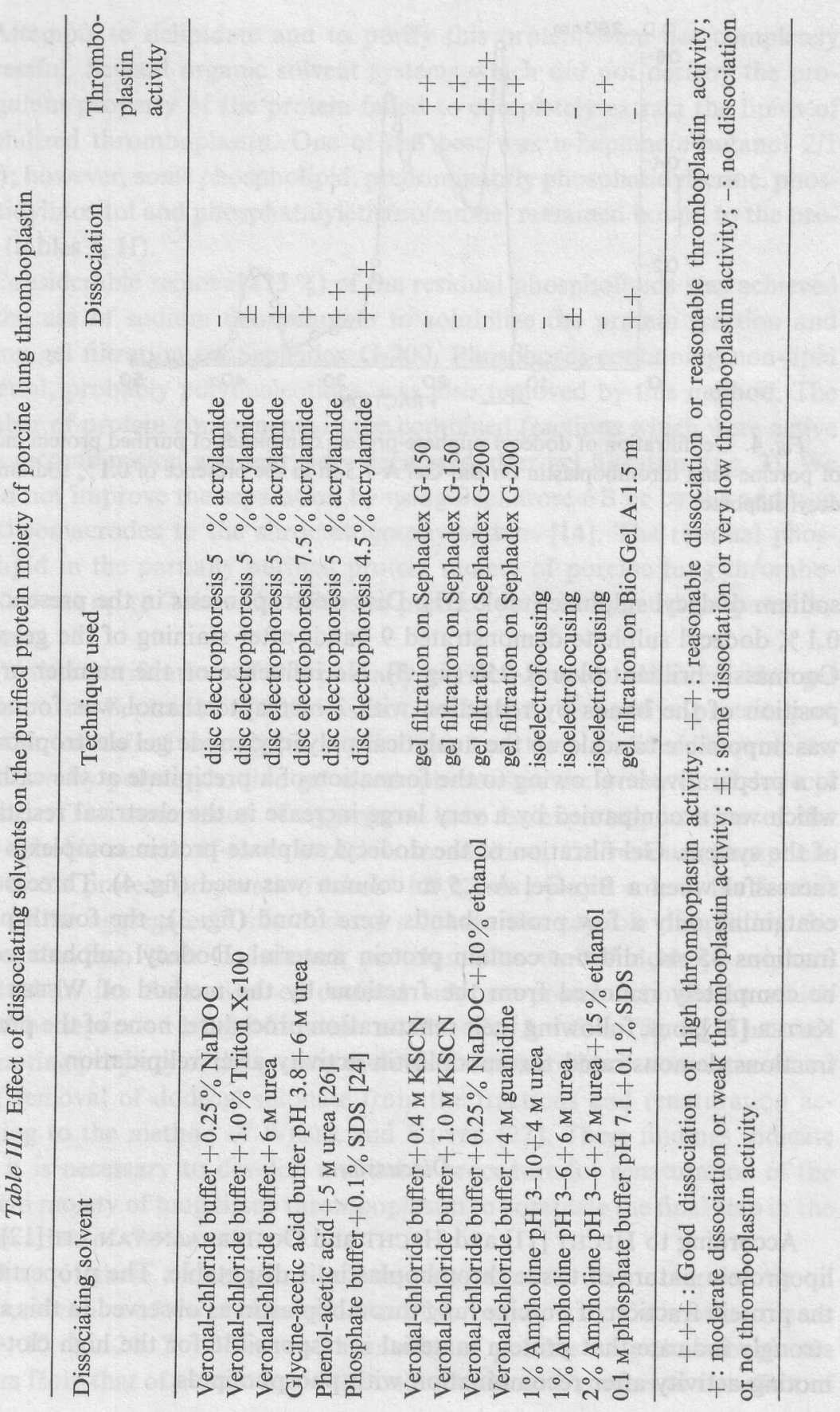




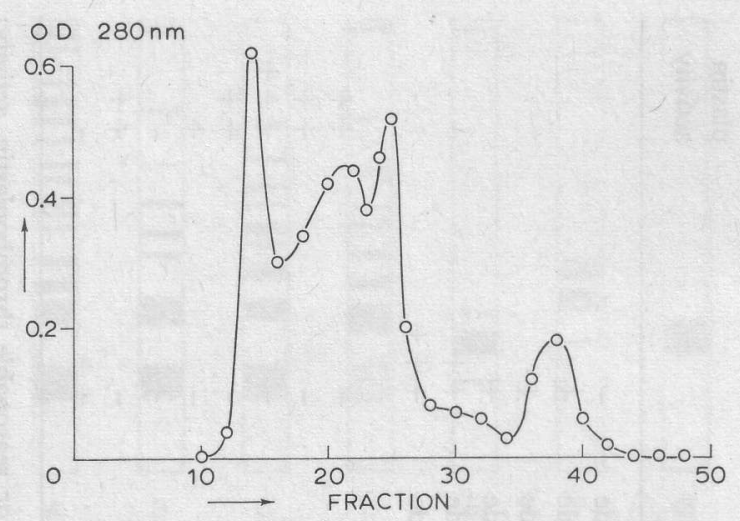

Fig. 4. Gel filtration of dodecyl sulphate-protein complexes of purified protein moiety of porcine lung thromboplastin on Bio-Gel A-1.5 $\mathrm{m}$ in the presence of $0.1 \%$ sodium dodecyl sulphate.

sodium dodecyl sulphate (table III). Disc electrophoresis in the presence of $0.1 \%$ dodecyl sulphate demonstrated 9 bands after staining of the gel with Coomassie brilliant blue R-250 (fig. 3). No influence on the number or the position of the bands by reduction with 2 -mercaptoethanol was found. It was impossible to scale up the analytical polyacrylamide gel electrophoresis to a preparative level owing to the formation of a precipitate at the cathode which was accompanied by a very large increase in the electrical resistance of the system. Gel filtration of the dodecyl sulphate-protein complexes was successful when a Bio-Gel A-1.5 m column was used (fig. 4). Three peaks containing only a few protein bands were found (fig. 3); the fourth peak, fractions $35-44$, did not contain protein material. Dodecyl sulphate could be completely removed from the fractions by the method of WEBER and KUTER [27], but, following their renaturation procedure, none of the protein fractions demonstrated thromboplastin activity after relipidation.

\section{Discussion}

According to Hecht [11] and Hecht and OosterbaAn-VAN Lit [12], the lipoprotein nature of tissue thromboplastin is disputable. The properties of the protein fraction of porcine lung thromboplastin as observed in this study strongly indicate that protein material is responsible for the high clot-promoting activity after recombination with phospholipids. 
Attempts to delipidate and to purify this protein were not completely successful. Several organic solvent systems which did not destroy the procoagulant property of the protein failed to completely extract the lipids of lyophilized thromboplastin. One of the best was $n$-heptane/n-butanol $2 / 1$ (v/v); however, some phospholipid, predominantly phosphatidylserine, phosphatidylinositol and phosphatidylethanolamine, remained bound to the protein (tables I, II).

Considerable removal $(75 \%)$ of the residual phospholipids was achieved by the use of sodium deoxycholate to solubilize the protein fraction and during gel filtration on Sephadex G-200. Phosphorus-containing non-lipid material, probably polynucleotides, was also removed by this method. The number of protein components in the combined fractions which were active after recombination was markedly decreased after gel filtration (fig. 3). We could not improve the separation by using Sepharose 6B or by the addition of Rheomacrodex to the chromatography system [14]. The residual phospholipid in the partially purified protein moiety of porcine lung thromboplastin was up to 7 times less than in purified protein moieties prepared by others.

Further purification of the partially purified protein obtained after gel filtration on Sephadex G-200 was not successful. The active protein preparation contained aggregates consisting of at least 9 different proteins, as shown by polyacrylamide gel electrophoresis in the presence of dodecyl sulphate. The occurrence of aggregates is to be expected, in view of the hydrophobic nature of these proteins. In addition, the residual phospholipids in the protein preparation (about $1.0 \%$ ) may play a role in the formation of the aggregates. Only dodecyl sulphate was capable of splitting the aggregates into their constituent proteins. The use of dodecyl sulphate resulted in the formation of dodecyl sulphate-protein complexes which could be separated by gel filtration on Bio-Gel A-1.5 m (fig. 4). The clotpromoting property of the protein moiety of thromboplastin was not restored after removal of dodecyl sulphate from the fractions and renaturation according to the method of WEBER and KUTER [27]. These findings indicate that it is necessary to develop a suitable procedure for renaturation of the protein moiety of lung tissue thromboplastin to complete the final step in the purification of the protein.

Most of these findings are in general agreement with observations on the purification of the protein moieties of thromboplastin from other tissues $[2,9,10,15,20,21]$. The protein moiety of porcine lung thromboplastin differs from that of human brain thromboplastin with respect to the effect of 
dodecyl sulphate, thus preventing the use of this detergent in the purification procedure. Different values, ranging from 47,000 to 330,000 , have beer reported for the molecular weights of the thromboplastin protein moieties The molecular weight of the porcine lung protein (about 300,000) wa roughly the same as that of one protein found in a bovine lung preparation (molecular weight 330,000) [21].

However, an observed molecular weight will strongly depend on the appearance of aggregates. This possibly explains the difference in the molecular weight of the protein moiety of human brain thromboplastin observed by BJøRKLID et al. [2] (molecular weight 53,000) and by GONMORI and TAKEDA [10] (molecular weight 200,000). The same might apply to the molecular weight of the protein moiety of bovine lung thromboplastin found by NEMERSON and PITLICK [21] (molecular weight 220,000 and 330,000) an by LIU and MCCOY [15] (molecular weight 56,000).

Our results demonstrate that the purification of the protein moiety of porcine lung thromboplastin (and probably also of other thromboplastins) is complicated by the occurrence of the protein in aggregates with other proteins. In this respect, the use of incorrect methods to check the homogeneity of such a preparation can show a single protein which is only apparent. A procedure which dissociates these aggregates without denaturation of the protein or an effective renaturation method should be developed to complete the purification.

\section{References}

1 Bartlett, G.R.: Phosphorus assay in column chromatography. J.biol. Chem. 234: 466-468 (1959).

2 Bjørklid, E.; SToRM, E., and Prydz, H.: The protein component of human brain thromboplastin. Biochem. biophys. Res. Commun. 55: 969-976 (1973).

3 BLIGH, E. G. and DYER, W.J.: A rapid method of total lipid extraction and purification. Can. J. Biochem. Physiol.37: 911-917 (1959).

4 BRoEKHUYSE, R.M.: Quantitative two-dimensional thin-layer chromatography of blood phospholipids. Clinica chim. Acta 23: 457-461 (1969).

5 Chargaff, E.; Moore, D.H., and BeNDich, A.: Ultracentrifugal isolation from lung tissue of a macromolecular protein component with thromboplastic properties. J. biol. Chem. 145: 593-603 (1942).

6 CLARKE, N.: Intracellular location of tissue thromboplastin and possible relation of fibrin deposits in human neoplasms. Nature, Lond. 205: 608-610 (1965).

7 Clarke, N. and O'Meara, R.A.Q.: Intracellular location of thromboplastic activity in the cells of human chorion. Br.J.Haemat. 12: 536-545 (1966). 
8 DeUtSCH, E.; IRSIGLER, K. und Lomoschitz, H.: Studien über Gewebethromboplastin. I. Reinigung, chemische Charakterisierung und Trennung in einen Eiweiss-und Lipoidanteil. Thromb. Diath. haemorrh. 12: 12-34 (1964).

9 Gonmori, H. and TAKedA, Y.: Properties of canine tissue thromboplastins from brain, lung, arteries, and veins. Am.J.Physiol.229: 618-626 (1975).

10 GONMORI, H. and TAKEDA, Y.: Properties of human tissue thromboplastins from brain, lung, arteries, and placenta. Thromb. Haemostas. 36: 90-103 (1976).

11 Heсhт, E.: Chemical nature of human brain thromboplastin. Nature, Lond.214: 197-198 (1967).

12 Hecht, E. und Oosterbaan-van Lit, W. L.: Über die chemische Natur des Thromboplastins aus menschlicher Hirnsubstanz. Thromb. Diath. haemorrh. 18: 223-240 (1967).

13 Hecht, E. and WijngaARds, G.: On the functional resynthesis of thromboplastin ('TP') from its fractions and various substitutes. Thromb. Diath. haemorrh. 21 : 546-560 (1969).

14 Hellsing, K.: Gel chromatography in eluents containing polymers. J. Chromat.36: 170-180 (1968).

15 LIU, D.T.H. and McCoy, L.E.: Tissue extract thromboplastin: quantitation, fractionation and characterization of protein components. Thromb.Res.7: 199-211 (1975).

16 Lowry, O.H.; Rosebrough, N.J.; FArR, A. L., and Randall, R. J.: Protein measurement with the Folin phenol reagent. J. biol. Chem. 193: 265-275 (1951).

17 Mrlss, C.A.: Chemical nature of tissue coagulins. J.biol. Chem.46: 135-165 (1921).

18 Nemerson, Y.: The reaction between bovine brain tissue factor and factors VII and X. Biochemistry, N.Y.5: 601-608 (1966).

19 Nemerson, Y.: The phospholipid requirement of tissue factor in blood coagulation. J.clin. Invest. 47: 72-80 (1968).

20 Nemerson, Y.: Characteristics and lipid requirements of coagulant proteins extracted from lung and brain: the specificity of the protein component of tissue factor. J.clin. Invest. 48: 322-331 (1969).

21 Nemerson, Y. and Pitlick, F.A.: Purification and characterization of the protein component of tissue factor. Biochemistry, N.Y. 9: 5100-5105 (1970).

22 Rouser, G.; Fleischer, S., and Yamamoto, A.: Two-dimensional thin layer chromatographic separation of polar lipids and determination of phospholipids by phosphorus analysis of spots. Lipids 5: 494-496 (1970).

23 SCANU, A.: Forms of human serum high density lipoprotein protein. J.Lipid Res.7: 295-306 (1966).

24 Shapiro, A.L.; Vinuela, E., and Maizel, J.V.: Molecular weight estimation of polypeptide chains by electrophoresis in SDS-polyacrylamide gels. Biochem. biophys. Res. Commun. 28: 815-820 (1967).

25 Studer, A.: Festschrift Emil Barell, p. 229 (Hoffman-La Roche, Basel 1946).

26 TaKayama, K.; Maclennan, D.H.; Tzagoloff, A., and Stoner, C.D.: The electron transfer system. LXVII. Polyacrylamide gel electrophoresis of the mitochondria electron transfer complexes. Archs. Biochem. Biophys. 114: 223-230 (1966).

27 Weber, K. and Kuter, D.J.: Reversible denaturation of enzymes by sodium dodecyl sulfate. J.biol. Chem. 246: 4504-4509 (1971).

28 WiJngaARDS, G.: Investigations on the purification and lipid requirements of tissue thromboplastin; thesis, Utrecht (1972). 
29 Wijngaards, G.; van Deenen, L.L.M., and Hemker, H.C.: Reconstitution and lipid requirements of porcine tissue thromboplastin. Biochim. Biophys. Acta 488: 161-171 (1977).

30 WiJngaARds, G. and Hemker, H.C.: Determination of tissue thromboplastin activity. Haemostasis 6: 89-97 (1977).

31 WiLLIAMs, W.J.: The activity of lung microsomes in blood coagulation. J. biol. Chem. 239: 933-942 (1964).

32 WILLIAMS, W.J.: The activity of human placenta microsomes and brain particles in blood coagulation. J.biol. Chem. 241: 1840-1846 (1966).

33 WIILIAMS, W.J. and NorRIS, D.G.: Purification of a bovine plasma protein (factor VII) which is required for the activity of lung microsomes in blood coagulation. J.biol. Chem. 241: 1847-1856 (1966).

Dr. G.WijngaARDS, Gaubius Institute, Health Research Organization TNO, Herenstraat $5 \mathrm{~d}$, Leiden (The Netherlands) 